\title{
Evaluation of fracture parameters of bond in stone masonry units bound with fibre reinforced mortar
}

\author{
M. T. Islam \& V. Bindiganavile \\ Department of Civil \& Environmental Engineering, \\ University of Alberta, Canada
}

\begin{abstract}
This paper evaluates the fracture parameters of bond in stone masonry units bound with plain and fibre reinforced mortar. Sandstone blocks were joined together with a modern Type S mortar conforming to CSA A 179-04. A companion series was examined employing a hydraulic lime mortar used in the repointing of historical masonry. Based on a previous study, polypropylene micro fibres were incorporated at up to $0.5 \%$ by volume to achieve superior crack growth resistance. The study reports relevant fracture parameters including the critical stress intensity factor, the critical crack length and the critical crack mouth opening displacements. The masonry units were subjected to quasi static flexure as per ASTM and dynamic bending via a drop weight impact machine which generated stress rates up to $10^{7} \mathrm{kPa} / \mathrm{s}$. The results show an improvement in the bond strength, but varied fracture performance between the Type $\mathrm{S}$ and hydraulic lime mortars, as a result of fibre reinforcement.
\end{abstract}

Keywords: masonry bond, fracture analysis, fibre reinforced mortar.

\section{Introduction}

Stone masonry is a layered composite consisting of stone blocks bonded with a mortar to form a unit. The performance of the masonry unit is dictated not so much by the properties of the components, but by the bond between the mortar and the stone block $[1,2]$. A study of the relationship between the compressive strength of a masonry composite prism and the bond strength showed that an increase in the bond strength resulted in an increase in the compressive strength 
of the masonry unit even while the mortar strength remained constant [3]. The failure mode of masonry prisms depends upon the bond strength, for a weak mortar leads to failure at the mortar-block interface where as a strong bond leads to fracture in the block $[4,5]$. For masonry prisms with blocks stronger than the mortar, the compressive strength of the masonry prism was found to be less sensitive to bond strength $[2,4]$.

The role of fibres in improving the mechanical properties of concrete is wellknown [6] to result in significant improvement to the tensile strength and postcrack residual strength in mortars under impact loading [7, 8]. Fibre improves the energy absorption capacity of concrete by enhancing its post-peak stresstransfer capability and hence is an effective way of improving concrete's resistance to impact load. However, the choice of fibre type, length, and shape greatly influences the composite performance. There are various types of fibre, such as metallic, mineral, polymeric, and natural fibres. Short, discrete, polymeric fibres increase the energy dissipated by concrete under impact loading [9], sometimes exceeding in DIF over steel fibres [10]. However, very little is known about their performance in mortars used for masonry. Armwood et al. [11] concluded that the total fibre content should be restricted to an upper limit of $0.6 \%$ volume fraction. Recently Chan and Bindiganavile [12] studied the effect of polypropylene micro-fibres on the flexural behaviour of hydraulic lime mortar up to $0.5 \%$ volume fraction. Fibres decreased the strain-rate sensitivity of the flexural response. The fracture toughness was higher with fibres but there was an optimum fibre content at $0.25 \%$ volume fraction for dynamic crack growth resistance. Studies on the aggregate-paste interface register an improvement with microfibres [13]. However, it is not just the strength but also the possible changes to the failure mechanism that define the composite response in stone masonry.

While a lot of effort has been spent on studying fibre-reinforced cementitious systems, there is little information on the effect of fibres on the fracture response of the stone-mortar bond in masonry. A major objective of this study is to characterize the fracture behaviour of bond in the masonry units bound with fibre reinforced mortar using the concepts of linear elastic fracture mechanics based on the Griffith energy criteria as applied to quasi-brittle materials [14]. A Portland cement-lime mortar (Type S) and a traditional Hydraulic Lime mortar seen in historical structures were chosen along with locally available sandstone. Based on a previous study [12], polypropylene micro fibres were incorporated at up to $0.5 \%$ by volume. The flexural response of the masonry units was established via standardized quasi-static tests while an instrumented drop-weight impact testing machine was utilized to generate the high stress-rates, up to $10^{7} \mathrm{kPa} / \mathrm{s}$. The results were analyzed to derive fracture parameters including, the critical stress intensity factor, the critical crack length and the critical crack mouth opening displacements and compare the fibre efficiency in the two types of mortar. 


\section{Experimental details}

\subsection{Materials and composition}

Sandstone taken from the Paskapoo formation local to Alberta (Figure 1a) was used to prepare the masonry units. The chemical composition of the Type $\mathrm{S}$ Portland cement-lime binder as adopted from the manufacturer is shown in Table 1. A natural hydraulic lime (NHL-2) with a targeted compressive strength of 2 MPa (at 180 d) was sourced from France. The physical properties for NHL-2 are described in Table 2 [15], while the chemical composition is shown in Table 3 [16]. In addition to a plain mortar, fibre-reinforced mixes were prepared with polypropylene microfibres (Figure 2) introduced at dosage rates of $0.25 \%$ and $0.50 \%$ by volume fraction $\left(\mathrm{V}_{\mathrm{f}}\right)$. For the plain mortar, the water-to-binder ratio was suitably adjusted to achieve a flow between $100-115 \%$ in order to meet the workability criterion per CSA A 179-04 [17]. A blended sand was used as the

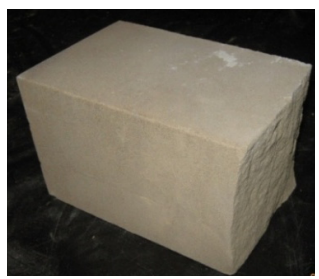

a)

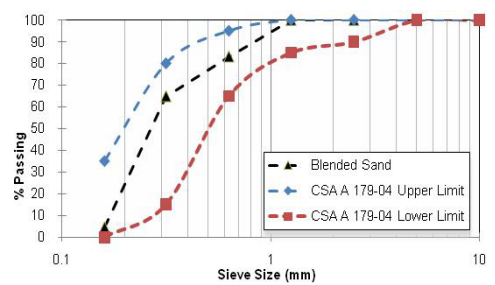

b)

Figure 1: a) Sandstone block; b) grain size distribution of the fine aggregate in mortar.

Table 1: Chemical composition of type $\mathrm{S}$ cement binder [\% mass].

\begin{tabular}{|c|c|c|c|c|c|c|}
\hline $\mathrm{CaCO}_{3}$ & $\begin{array}{c}\mathrm{SiO}_{2}(\text { Crystalline } \\
\text { silica) }\end{array}$ & $\mathrm{Ca}(\mathrm{OH})_{2}$ & $\mathrm{CaSO}_{4}$ & $\mathrm{MgO}$ & $\mathrm{CaO}$ & $\begin{array}{c}\text { Portland } \\
\text { cement }\end{array}$ \\
\hline $20-50$ & $<10$ & $0-20$ & $5-10$ & $0-4$ & $0-1$ & $30-75$ \\
\hline
\end{tabular}

Table 2: $\quad$ Physical properties of NHL-2 [15].

\begin{tabular}{|c|c|c|c|c|c|c|c|}
\hline $\begin{array}{c}\text { Bulk } \\
\text { density }\end{array}$ & & ess & $\begin{array}{c}\text { Sound- } \\
\text { ness }\end{array}$ & $\begin{array}{c}\text { Free } \\
\text { water } \\
\text { content }\end{array}$ & Penetration & $\begin{array}{c}\text { Air } \\
\text { content }\end{array}$ & Setting time \\
\hline \multirow[b]{2}{*}{$\left(\mathrm{kg} / \mathrm{m}^{3}\right)$} & \multicolumn{2}{|c|}{$(\%)$} & \multirow[b]{2}{*}{$(\mathrm{mm})$} & \multirow[b]{2}{*}{$(\%)$} & \multirow[b]{2}{*}{$(\mathrm{mm})$} & \multirow[b]{2}{*}{$(\%)$} & \multirow[b]{2}{*}{ (hour) } \\
\hline & $\begin{array}{c}0.09 \\
\mathrm{~mm}\end{array}$ & $\begin{array}{c}0.2 \\
\mathrm{~mm}\end{array}$ & & & & & \\
\hline $400-800$ & $\leq 15$ & $\leq 5$ & $\leq 20$ & $\leq 2$ & $>20$ and $<50$ & $\leq 20$ & $>1$ and $\leq 15$ \\
\hline
\end{tabular}

Table 3: Chemical composition of NHL-2 (\% related to original dry lime) [16].

\begin{tabular}{|c|c|c|c|c|c|c|c|c|}
\hline $\mathrm{CaO}$ & $\mathrm{LOI}$ & $\mathrm{SiO}_{2}$ & $\mathrm{MgO}$ & $\mathrm{Al}_{2} \mathrm{O}_{3}$ & $\mathrm{SO}_{3}$ & $\mathrm{Al}_{2} \mathrm{O}_{3}$ & $\mathrm{Fe}_{2} \mathrm{O}_{3}$ & $\mathrm{Na}_{2} \mathrm{O}$ \\
\hline 54.26 & 15 & 12.57 & 7.65 & 5.42 & 2.13 & 1.35 & 1.16 & 0.34 \\
\hline
\end{tabular}




\begin{tabular}{ll}
\hline Specific Gravity & 0.91 \\
\hline Fibre Length $(\mathrm{mm})$ & 20 \\
\hline Density $\left(\mathrm{kg} / \mathrm{m}^{3}\right)$ & 910 \\
\hline Tensile Strength $(\mathrm{MPa})$ & 450 \\
\hline Modulus of Elasticity $(\mathrm{MPa})$ & 3450 \\
\hline Denier & 3 \\
\hline
\end{tabular}

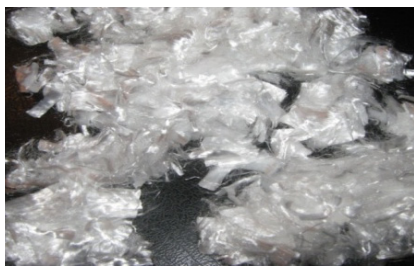

Figure 2: $\quad$ Polypropylene microfibres used in this study.

fine aggregate, to meet the grading criterion as shown in Figure 1b). This gradation is particularly designed to ensure superior durability in the context of historical stone masonry [18].

\subsection{Specimen preparation}

The Type $\mathrm{S}$ and hydraulic lime mortars were mixed in a mortar mixer with rotation about the horizontal axis to ensure satisfactory blending of the fine aggregates, binder, water, and microfibres. The mixing sequence, crucial to achieving the desired workability, was as follows: First, $2 / 3$ of the mix water was added to the mixer with half the fine aggregates and the entire binder. After 2-3 minutes of mixing, the remaining sand and water was added with an additional 8-10 minutes of mixing. At this point, for the fibre-reinforced mortars, polypropylene microfibres were added to the mixture. These fibres were fluffed through an air-jet to ensure maximum dispersion in the mix. After 2-3 minutes of further blending, the workability of the fresh mortar was determined by using a flow table as per ASTM C1437 [19]. Whereas the slump flow in plain mortars was as required by the standard, introducing fibres led to a significant drop (Table 4). However, no change was made to the mix composition or the proportion to restrict the number of variable parameters during analysis. The

Table 4: $\quad$ Mix design of type S and hydraulic lime mortar (HLM).

\begin{tabular}{|c|c|c|c|c|c|c|c|}
\hline \multirow{2}{*}{$\begin{array}{c}\text { Mix \& } \\
\text { Designation }\end{array}$} & \multirow{2}{*}{$\begin{array}{l}\text { Fibre } \\
\text { content } \\
\left(\% \mathrm{~V}_{\mathrm{f}}\right)\end{array}$} & \multirow{2}{*}{$\begin{array}{c}\text { NHL } \\
\left(\mathrm{kg} / \mathrm{m}^{3}\right)\end{array}$} & \multirow{2}{*}{$\begin{array}{l}\text { Type } \mathrm{S} \\
\text { Cement } \\
\left(\mathrm{kg} / \mathrm{m}^{3}\right)\end{array}$} & \multirow{2}{*}{$\begin{array}{c}\text { Sand } \\
\left(\mathrm{kg} / \mathrm{m}^{3}\right)\end{array}$} & \multirow{2}{*}{$\begin{array}{c}\text { Water } \\
\left(\mathrm{kg} / \mathrm{m}^{3}\right)\end{array}$} & \multicolumn{2}{|c|}{ Slump Flow } \\
\hline & & & & & & $\begin{array}{c}\text { HLM } \\
(\%)\end{array}$ & $\begin{array}{c}\text { Type S } \\
\text { mortar } \\
(\%)\end{array}$ \\
\hline $0.00 \% \mathrm{~V}_{\mathrm{f}}$ Fibre & 0.0 & 400 & - & 1200 & 400 & 103 & - \\
\hline $0.25 \% \mathrm{~V}_{\mathrm{f}}$ Fibre & 0.25 & 400 & - & 1200 & 400 & 48 & - \\
\hline $0.50 \% \mathrm{~V}_{\mathrm{f}}$ Fibre & 0.5 & 400 & - & 1200 & 400 & 39 & - \\
\hline $0.00 \% \mathrm{~V}_{\mathrm{f}}$ Fibre & 0.0 & - & 200 & 1200 & 400 & - & 106 \\
\hline $0.25 \% \mathrm{~V}_{\mathrm{f}}$ Fibre & 0.25 & - & 200 & 1200 & 400 & - & 37 \\
\hline $0.50 \% \mathrm{~V}_{\mathrm{f}}$ Fibre & 0.5 & - & 200 & 1200 & 400 & - & 23 \\
\hline
\end{tabular}


masonry units were built to have the dimensions of $100 \mathrm{~mm} \times 100 \mathrm{~mm} \times 350$ $\mathrm{mm}$ (Figure 3a). Two sandstone blocks $(100 \mathrm{~mm}$ x $100 \mathrm{~mm} \times 150 \mathrm{~mm})$ were joined with mortar to produce each masonry unit. The specimens were left in their moulds at room temperature and humidity to be demoulded after 7 days for Type S mortar and 28 days for Hydraulic Lime mortar, at which time they were stored under ambient temperature and humidity $\left(18-24^{\circ} \mathrm{C}\right.$ and $30-50 \%$ relative humidity) for another 28 days before testing for Type $\mathrm{S}$ mortar and 180 days for Hydraulic Lime mortar.

a)

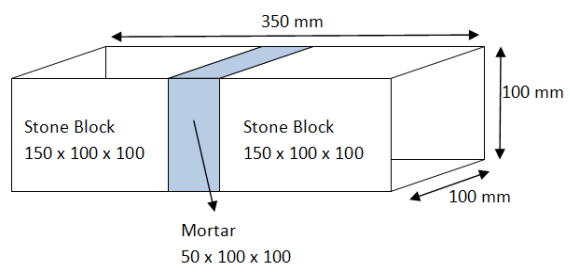

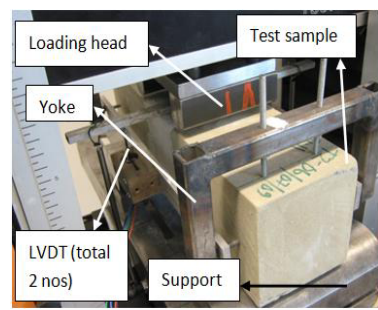

b)

Figure 3: a) Schematic of prisms for flexural testing of masonry unit, b) test setup for quasi-static flexure.

\subsection{Test setup - quasi static flexure}

Quasi-static flexure tests (Figure 3b) were conducted as per ASTM C 1609 [20] with a 4-point loading on the masonry units, which were supported using a 300 mm clear span. Two LVDTs were attached on either side of the specimen via a yoke to measure the midspan displacement, while accounting for support settlement if any.

\subsection{Test setup - dynamic flexure}

An instrumented drop weight impact tester (Figure 4a) was employed to generate the higher rates of flexural loading. It consists of a $62 \mathrm{~kg}$ hammer that may be raised to $2.5 \mathrm{~m}$, which gives it a maximum impact potential of $1.0 \mathrm{~kJ}$. For each of the mixes in Table 3, three masonry units were examined under impact from two separate heights, namely $250 \mathrm{~mm}$ and $500 \mathrm{~mm}$. These drop heights generate 2.20 $\mathrm{m} / \mathrm{s}$ and $3.10 \mathrm{~m} / \mathrm{s}$, respectively, if friction is ignored. A piezoelectric accelerometer was attached below each specimen at midspan to gather the acceleration history. The data from the load cell and the accelerometer was recorded at 100,000 Hz. Two high-speed cameras were also employed to capture images at 10,000 frames per second. The high-speed images were used for crack growth studies in fracture analysis. A trigger mechanism was installed so that all four sets of data were synchronized to the same time-stamp (Figure 4b). It is well known that inertial effects are associated with a suddenly applied load on brittle matrix systems and these must be accounted for in order to evaluate the true stressing load experienced by the material [21]. For a beam subjected to 3-point 
bending under impact, the stressing load, $P_{b}(t)$, is obtained by subtracting the generalized inertial load on the specimen, $P_{i}(t)$, from the tup load, $P_{t}(t)$, represented by [22]:

$$
P_{b}(t)=P_{t}(t)-P_{i}(t) \text { and } P_{i}(t)=\rho A a_{0}(t)\left[\frac{l}{3}+\frac{8(o v)^{3}}{3 l^{2}}\right]
$$

where, $a_{o}(t)$ is the acceleration at midspan of the beam at time, $t ; \rho$ is the mass density for the beam material; $A$ is the cross-sectional area of the beam; $l$ is the clear span of the beam; and $o v$ is the length of the overhang of the beam.

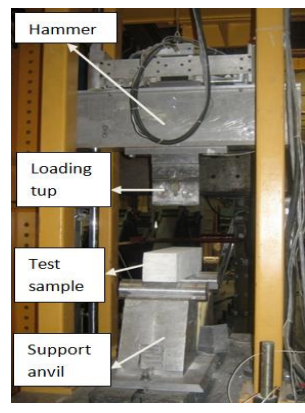

a) Drop weight impact machine

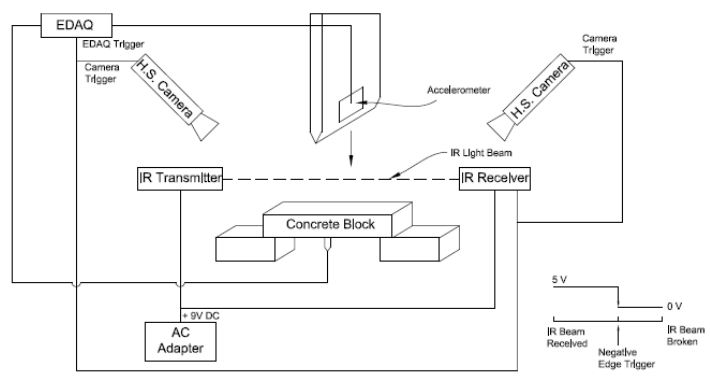

b) Schematic of trigger mechanism for high-speed data collection

Figure 4: $\quad$ Setup for dynamic testing.

\section{Results and discussion}

\subsection{Flexural response}

\subsubsection{Type $S$ mortar}

The quasi-static flexural response of the masonry units bound with Type $\mathrm{S}$ mortar is shown in Figure 5a, while their response under impact loading is shown for a drop-height of $250 \mathrm{~mm}$ and $500 \mathrm{~mm}$ in Figure $5 \mathrm{~b}$ and Figure 5c, respectively. Rao et al. [1] observed that it is not the strength of the mortar but the bond strength which directly correlates to the performance of the masonry

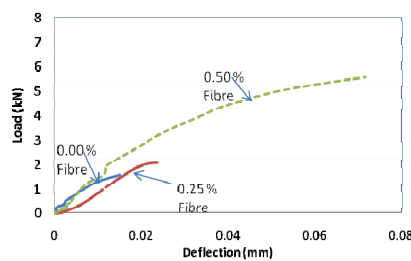

a)

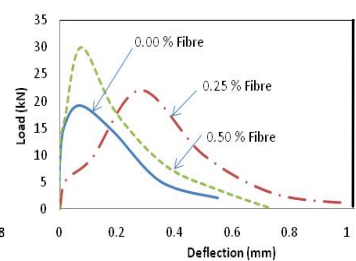

b)

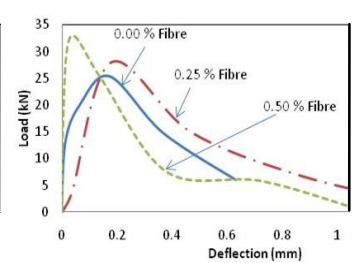

c)

Figure 5: Flexural load-deflection response for masonry unit bound with type $\mathrm{S}$ mortar a) under quasi-static flexure b) impact - drop height of $250 \mathrm{~mm}$ and c) impact - drop height of $500 \mathrm{~mm}$. 
unit. From Figure 5 and also from Table 5, it is clear that fibre reinforcement consistently improved the flexural bond strength and MOR (Modulus of Rupture) at all rates of loading. Of considerable interest was the failure mode in each case. Whereas those units bound with plain mortar failed at the mortar block interface (Figure 7a), the masonry units bound with fibre-reinforced mortars consistently failed through fracture in the stone block (Figure 7b). This transition in the mode of failure implies an improvement in the stone mortar interface in the presence of discrete microfibres. The increase in the bond strength is likely due to a combination of changes to the paste-rock interface in the presence of microfibres. Banthia and Dubeau [23] believe this happens due to the reduction in paste shrinkage.

Table 5: $\quad$ Flexural response of masonry units bound with type S mortar.

\begin{tabular}{|c|c|c|c|c|c|c|c|c|}
\hline \multirow[t]{2}{*}{ Tests } & \multirow{2}{*}{$\begin{array}{c}\text { Fibre } \\
(\%)\end{array}$} & \multicolumn{3}{|c|}{ Peak Load (kN) } & \multirow{2}{*}{$\begin{array}{c}\text { MOR } \\
(\mathrm{MPa}) \\
\text { value }\end{array}$} & \multirow{2}{*}{$\begin{array}{c}\mathrm{K}_{\mathrm{IC}} \\
\mathrm{MPa}^{*} \sqrt{(\mathrm{m})}\end{array}$} & \multirow{2}{*}{$\begin{array}{l}a_{\text {eff,c }} \\
(\mathrm{mm})\end{array}$} & \multirow{2}{*}{$\begin{array}{c}\mathrm{CMOD}_{\mathrm{c}} \\
(\mathrm{mm})\end{array}$} \\
\hline & & value & $\sigma$ & $\begin{array}{c}\mathrm{C}_{\mathrm{V}} \\
(\%)\end{array}$ & & & & \\
\hline \multirow{3}{*}{$\begin{array}{l}\text { Quasi static } \\
\text { tests }\end{array}$} & 0 & 1.58 & 0.24 & 15.46 & 0.47 & 0.03 & 1.61 & 0.02 \\
\hline & 0.25 & 2.08 & 0.10 & 4.76 & 0.62 & 0.04 & 1.00 & 0.03 \\
\hline & 0.5 & 5.58 & 1.07 & 18.70 & 1.67 & 0.05 & 1.57 & 0.07 \\
\hline \multirow{3}{*}{$\begin{array}{l}\text { Impact tests } \\
\text { drop height } \\
=250 \mathrm{~mm}\end{array}$} & 0 & 19.29 & 4.08 & 21.16 & 8.68 & 1.06 & 5.95 & 0.11 \\
\hline & 0.25 & 22.04 & 4.04 & 18.31 & 9.92 & 0.83 & 2.1 & 0.42 \\
\hline & 0.5 & 29.94 & 5.35 & 17.9 & 13.47 & 1.45 & 3.6 & 0.12 \\
\hline \multirow{3}{*}{$\begin{array}{l}\text { Impact tests } \\
\text { drop height } \\
=500 \mathrm{~mm}\end{array}$} & 0 & 25.47 & 10.21 & 40.10 & 11.46 & 1.29 & 4.0 & 0.26 \\
\hline & 0.25 & 28.00 & 6.63 & 23.68 & 12.60 & 0.74 & 2.28 & 0.27 \\
\hline & 0.5 & 32.76 & 9.87 & 30.12 & 14.74 & 1.73 & 4.90 & 0.04 \\
\hline
\end{tabular}

\subsubsection{Hydraulic lime mortar}

The quasi-static flexural response of those masonry units bound with HLM is shown in Figure 6a, while their response under impact loading is shown for a drop height of $250 \mathrm{~mm}$ and $500 \mathrm{~mm}$ in Figure $6 \mathrm{~b}$ and Figure $6 \mathrm{c}$, respectively. The mechanical properties as evaluated are listed in Table 6. The addition of fibres led to higher flexural bond strength at quasi-static and low impact loads.

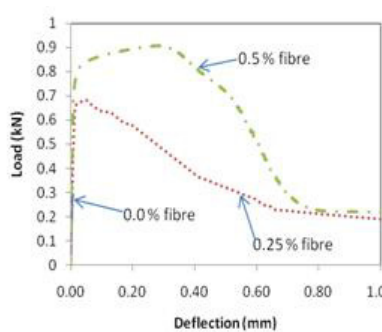

a)

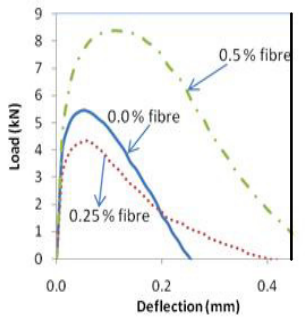

b)

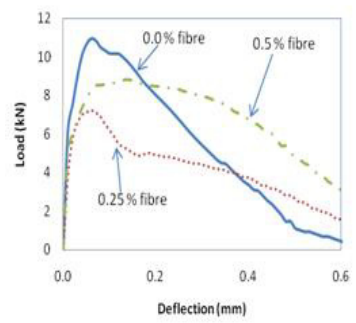

c)

Figure 6: Flexural load-deflection response for masonry unit bound with hydraulic lime mortar a) under quasi-static flexure b) impact - drop height of $250 \mathrm{~mm}$ and c) impact - drop height of $500 \mathrm{~mm}$. 
However, for the $500 \mathrm{~mm}$ drop, the strongest bond performance was with the plain HLM. The MOR (Modulus of Rupture) of masonry unit bound with hydraulic lime mortar as seen from table 6 is increased with the fibre addition. The role of fibres may be explained through an examination of the failure mode as illustrated in Figure $7 \mathrm{c}$ and Figure $7 \mathrm{~d}$. Whereas the mode of failure in the masonry units under quasi-static loading was through fracture at the mortarblock interface (Figure 7c), the failure plane transferred to within the mortar under dynamic loading (Figure 7d), particularly with fibre reinforcement. Once again, the bond strength appears to improve with fibre reinforcement. Such an effect on hydraulic lime mortars is likely due to the improved packing of hydration products at the paste-rock interface through modified wall effect and moisture dispersion, which lead to a densified transition zone [13]. So that the weakest section is no longer at the stone-mortar interface but within the bulk mortar region.

Table 6: Flexural response of masonry units bound with hydraulic lime mortar.

\begin{tabular}{|c|c|c|c|c|c|c|c|c|}
\hline \multirow[t]{2}{*}{ Tests } & \multirow{2}{*}{$\begin{array}{c}\text { Fibre } \\
(\%)\end{array}$} & \multicolumn{3}{|c|}{ Peak Load (kN) } & \multirow{2}{*}{$\begin{array}{l}\text { MOR } \\
(\mathrm{MPa})\end{array}$} & \multirow[t]{2}{*}{$\mathrm{K}_{\mathrm{IC}}$} & \multirow{2}{*}{$\begin{array}{l}a_{\text {eff,c }} \\
(\mathrm{mm})\end{array}$} & \multirow{2}{*}{$\begin{array}{c}\mathrm{CMOD}_{\mathrm{c}} \\
(\mathrm{mm})\end{array}$} \\
\hline & & Value & $\sigma$ & $\mathrm{C}_{\mathrm{V}}(\%)$ & & & & \\
\hline \multirow{3}{*}{$\begin{array}{l}\text { Quasi static } \\
\text { tests }\end{array}$} & 0 & 0.29 & 0.07 & 24.07 & 0.09 & 0.01 & 3.01 & 0.01 \\
\hline & 0.25 & 0.72 & 0.12 & 16.72 & 0.22 & 0.02 & 4.02 & 0.07 \\
\hline & 0.5 & 0.92 & 0.2 & 22.16 & 0.28 & 0.05 & 6.00 & 0.38 \\
\hline \multirow{3}{*}{$\begin{array}{c}\text { Impact tests } \\
\text { drop height }= \\
250 \mathrm{~mm}\end{array}$} & 0 & 5.48 & 1.61 & 29.39 & 2.47 & 0.23 & 3.16 & 0.07 \\
\hline & 0.25 & 7.09 & 1.55 & 21.84 & 3.19 & 0.18 & 2.9 & 0.08 \\
\hline & 0.5 & 8.61 & 0.7 & 8.1 & 3.87 & 0.39 & 3.51 & 0.15 \\
\hline \multirow{3}{*}{$\begin{array}{c}\text { Impact tests } \\
\text { drop height = } \\
500 \mathrm{~mm}\end{array}$} & 0 & 11.14 & 5.95 & 53.40 & 5.01 & 0.47 & 3.39 & 0.08 \\
\hline & 0.25 & 9.35 & 5.95 & 63.64 & 4.21 & 0.28 & 2.49 & 0.08 \\
\hline & 0.5 & 12.85 & 2.39 & 18.6 & 5.78 & 0.46 & 5.37 & 0.19 \\
\hline
\end{tabular}

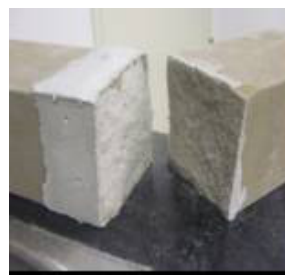

a)

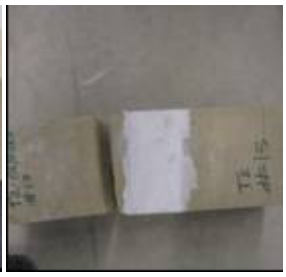

b)

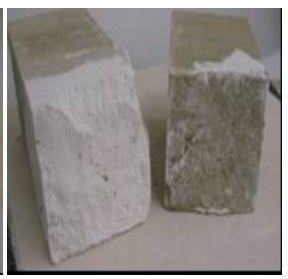

c)

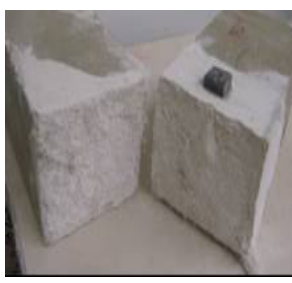

d)

Figure 7: $\quad$ Modes of failure in masonry units: a) plain type S mortar; b) fibrereinforced type $\mathrm{S}$ mortar; c) plain hydraulic lime mortar; d) fibrereinforced hydraulic lime mortar.

\subsection{Fracture toughness}

The fracture toughness of masonry units bound with plain and fibre reinforced mortar were evaluated for three different loading rates based on the load deflection graphs shown in Figures 5 and 6. For fracture analysis, the initial 
crack length and depth was assumed to be zero as there was no notch in the specimen. A notch was deliberately not introduced since the failure plane was not constant across different fibre contents or stress-rates.

As seen in Figure 7, where as plain Type S mortar led to failure at the stonemortar interface (Figure 7a), adding fibres moved the failure plane to within the stone block (Figure 7b). Again, where as plain HLM mortar led to failure at the interface (Figure 7c), it moved to within the mortar upon adding fibres, especially under dynamic loads (Figure 7d). For quasi-static loading, the crack mouth opening displacement (CMOD) was taken as 4/3 times the mid-point deflection [24]. For dynamic loading, the relationship between CMOD and midpoint deflection were evaluated by analysing images captured by two high speed cameras. For Type S mortar, the CMOD/mid-point deflection was 1.5 and for the HLM, this ratio was 4/3. By using the plots in Figures 5 and 6 and this ratio between CMOD and the mid-point deflection for different loading rates and different types of mortar, crack growth resistance curves were generated as shown in Figure 8 and Figure 9. The effective crack length, $a_{\text {eff }}$ and the stress intensity factor, $\mathrm{K}_{\mathrm{I}}$ were calculated as per the procedure described by Chan and Bindiganavile [12]. The critical stress intensity factor also known as the fracture toughness, $\mathrm{K}_{\mathrm{IC}}$, is the maximum value of $\mathrm{K}_{\mathrm{I}}$ in Figure 8 and Figure 9 which are

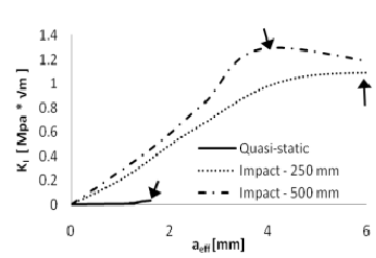

a)

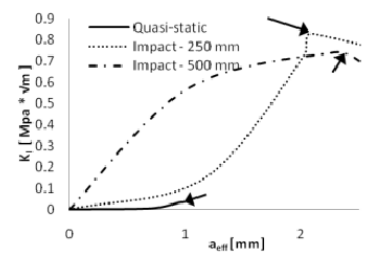

b)

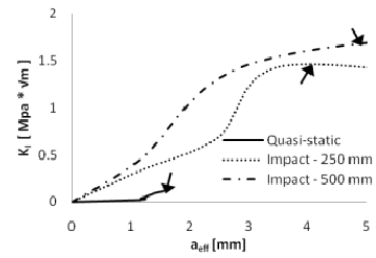

c)

Figure 8: Crack growth resistance in masonry unit bound with type $\mathrm{S}$ mortar at different stress-rates a) $0.0 \%$ fibre content b) $0.25 \%$ fibre content and c) $0.5 \%$ fibre content $\uparrow\left(\right.$ denotes $\mathrm{k}_{\mathrm{i}}$ value corresponding to peak load point).

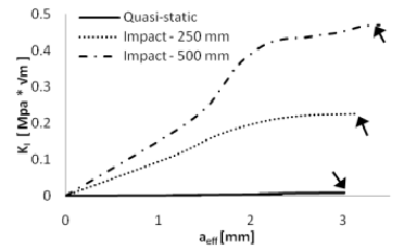

a)

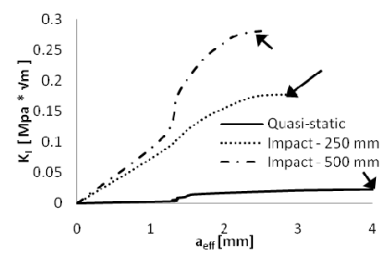

b)

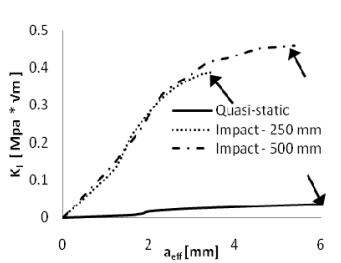

c)

Figure 9: Crack growth resistance in masonry unit bound with HLM at different stress-rates a) $0.0 \%$ fibre content b) $0.25 \%$ fibre content and c) $0.5 \%$ fibre content $\left(\uparrow\right.$ denotes $\mathrm{k}_{\mathrm{i}}$ value corresponding to peak load point). 
tabulated in Table 5 and Table 6 . As noticed, the $\mathrm{K}_{\mathrm{IC}}$ value increases with fibre addition and also with a rise in the loading rates for both types of mortar. It is clear from Figure 10 that fibre addition consistently increased fracture toughness for quasi-static loading for both types of mortar. But with dynamic loading, there was a drop in the fracture toughness at $0.25 \%$ fibre volume fraction. It is likely due to transfer of the failure plane away from the interface. However, raising the fibre content to $0.5 \%$ by volume improved the fracture toughness at all rates of loading.

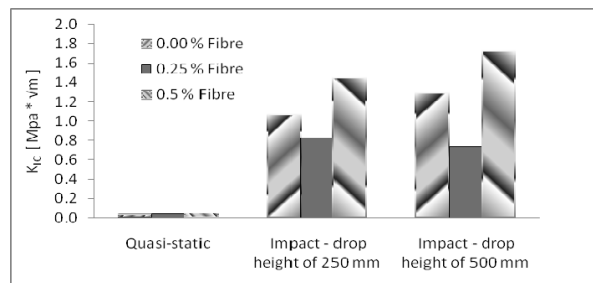

a)

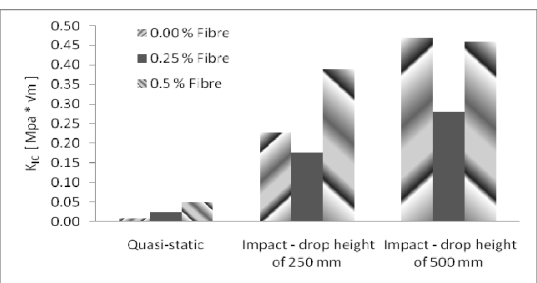

b)

Figure 10: Fracture toughness of masonry unit bound with plain and fibre reinforced mortar a) type $\mathrm{S}$ mortar b) hydraulic lime mortar.

\subsection{Stress-rate sensitivity}

The stress-rate sensitivity for the flexural bond strength and fracture toughness of masonry units bound with Type S mortar was expressed in terms of the dynamic impact factor (DIF) and is shown in Figure 11.

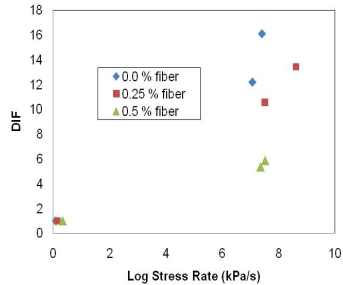

a)

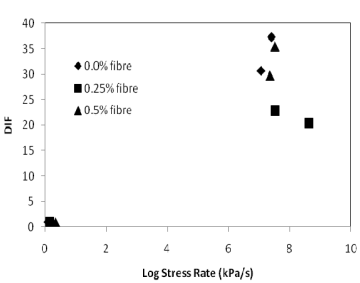

b)

Figure 11: Stress-rate sensitivity of masonry unit bound with type S mortar a) bond strength of masonry unit b) fracture toughness.

It is clear that adding fibres reduced the stress-rate sensitivity. As adding fibres shifted the failure plane from the mortar-block interface to within the stone block, it is likely that the lower stress-rate sensitivity of the joint is a reflection of the smaller rate sensitivity of sandstone compared to that of fibre-reinforced Type S mortars. It is also evident that fracture toughness of masonry units is more stress-rate sensitive than bond strength of masonry units bound with Type S mortar. 
The stress-rate sensitivity for the flexural bond strength and fracture toughness of masonry units bound with hydraulic lime mortar was expressed in terms of the dynamic impact factor (DIF) as shown in Figure 12. Again, adding fibres led to a drop in the rate sensitivity for both the flexural bond strength and the fracture toughness of the masonry unit. This is in line with the drop in rate sensitivity associated with fibre reinforcement of mortar and concrete. As with Type S mortar, the masonry units bound with HLM exhibit higher stress-rate sensitivity for fracture toughness in comparison to that for bond strength.

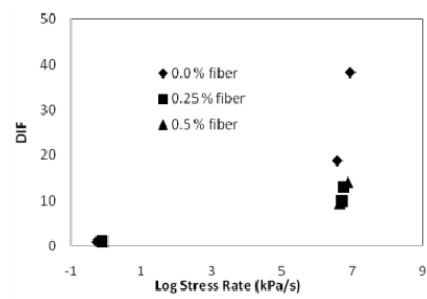

a)

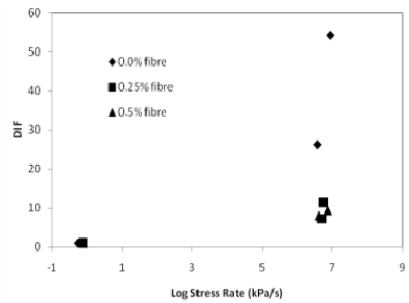

b)

Figure 12: Stress-rate sensitivity of masonry unit bound with hydraulic lime mortar a) bond strength of masonry unit b) fracture toughness.

\section{Concluding remarks}

This paper describes the fracture analysis of bond in sandstone masonry units bound with plain and fibre reinforced mortars. Linear elastic fracture mechanics was utilized for this analysis after considering the tested mortars as a quasibrittle material. Crack growth resistance curves were established for masonry units and the fracture parameters including $\mathrm{K}_{\mathrm{IC}}, \mathrm{a}_{\mathrm{eff}, \mathrm{c}}$ and $\mathrm{CMOD}_{\mathrm{c}}$ were evaluated for the bond with Type $\mathrm{S}$ and hydraulic lime mortars. Adding fibres led to a stronger bond but the fracture toughness was dependent upon the failure mode. While the bond strength and the bond fracture toughness were both sensitive to stress rate, fibres significantly reduced the dynamic impact factors in all cases.

\section{Acknowledgements}

This study was funded in part by the Network of Centres of Excellence on Intelligent Sensing for Innovative Structures (ISIS-Canada) and the Natural Sciences and Engineering Research Council (NSERC), Canada. The authors also thank the Masonry Contractors Association of Alberta (Northern Region) and Scorpio Masonry Inc., Edmonton for the supply of materials and technician time. The assistance of Public Works and Government Services, Canada is also gratefully acknowledged. 


\section{References}

[1] Rao, K.V., Reddy, B.V.V. \& Jagadish, K.S., Flexural bond strength of masonry using various blocks and mortars. Materials and Structures, 29, pp.119-124, 1996.

[2] Venkatarama, R. B.V. \& Vyas, U., Influence of shear bond strength on the compressive strength and stress-strain characteristics of masonry. Materials \& Structures, 41, pp. 1697-1712, 2008.

[3] Sarangapani, G., Venkatarama, R.B.V. \& Jagadish, K.S., Brick-mortar bond and masonry compressive Strength. Journal of Material \& Civil Eng, 17(2), pp. 229-237, 2005.

[4] Costigan, A. \& Pavía, S., Compressive, flexural and bond strength of brick/lime mortar masonry. Proceedings of PROHITEC-09, 1, pp.1609$1615,2009$.

[5] Gumeste, K.S. \& Venkatarama, R.B.V., Strength and elasticity of brick masonry prisms and wallettes under compression. Materials \& Structure, 29, pp. 241-253, 2006.

[6] ACI 544.R1, Report on fibre reinforced concrete. Committee 544, American Concrete Institute, Farmington Hills, MI, 66 pages, 1996.

[7] Glinicki, M.A., Toughness of fibre reinforced mortar at high tensile loading rates. ACI Materials Journal, 91(2), pp. 161-166, 1994.

[8] Bharatkumar, B.H. \& Shah, S.P., Impact resistance of hybrid fiber reinforced mortar. International RILEM Symposium on Concrete Science and Engineering, e-ISBN: 2912143926, 2004.

[9] Mindess, S. \& Vondran, G., Properties of concrete reinforced with fibrillated polypropylene fibres under impact loading. Cement and Concrete Research, 18(1), pp. 109-115, 1988.

[10] Bindiganavile, V. \& Banthia, N., Polymer and steel fiber reinforced cementitious composites under impact loading, Part 1: bond-slip response. ACI Materials Journal, 98(1), pp. 10-16, 2001.

[11] Armwood, C., Sorensen, A., Skourup, B. \& Erdogmus, E., Fibre reinforced mortar mixtures for the reconstruction and rehabilitation of existing masonry structures. Proceedings of AEI 2008-Building Integrated Solutions, ASCE, 10 pages, 2008.

[12] Chan, R. \& Bindiganavile, V., Toughness of fibre reinforced hydraulic lime mortar. Part-2: Dynamic response. Materials and Structures, 43, pp. 1445$1455,2010$.

[13] Bentur, A. \& Alexander, M.G., A review of the work the RILEM TC 159ETC: Engineering of the interfacial transition zone in cementitious composites. Materials and Structures, RILEM, 33, pp. 82-87, 2000.

[14] Radjy, F. \& Hansen, T.C., Fracture of hardened cement paste and concrete. Cement and Concrete research, 3, pp. 343-361, 1973.

[15] BS EN 459-1, Building limes - Part 1: Definitions, specification and conformity criteria. British Standards, 2002. 
[16] Lanas, J., Bernal, J.L.P., Bellob, M.A. \& Galindo, J.I.A., Mechanical properties of natural hydraulic lime based mortars. Cement and Concrete Research, 34(12), pp. 2191-2201, 2004.

[17] CSA A 179-04, Mortar and grout for unit masonry. Canadian Standards Association, Ontario, 2004.

[18] Maurenbrecher, A.H.P., Trischuk, K. \& Rousseau, M.Z., Review of factors affecting the durability of repointing mortars for older masonry. 9th Canadian Masonry Symposium, Fredericton, N.B. 9, pp. 1-12, 2001.

[19] ASTM C 1437, Standard test method for flow of hydraulic cement mortar. ASTM International, West Conshohocken, PA, 2007.

[20] ASTM C 1609-07. Standard test method for flexural performance of fiberreinforced concrete (using beam with third-point loading). ASTM International, West Conshohocken, PA, 2007.

[21] Chen, E.P. \& Sih, G.C., Transient response of cracks to impact loads. Mechanics of Fracture, 4: Elastodynamic crack problems, pp. 1-58, 1977.

[22] Banthia, N.P., Mindess, S., Bentur, A. \& Pigeon, M., Impact testing of concrete using a dropweight impact machine. Experimental Mechanics, 29(12), pp. 63-69, 1989.

[23] Banthia, N. \& Dubeau, S., Carbon and steel microfiber-reinforced cementbased composites for thin repairs. ASCE Journal of Materials in Civil Engineering, 6(1), pp. 88-99, 1994.

[24] Armelin, H.S., \& Banthia, N., Predicting the flexural postcracking performance of steel fiber reinforced concrete from the pullout of single fibers. ACI Material Journal, 94(1), pp. 18-31, 1997. 